\title{
Free Floating Ventricular Shunt Catheter Between Lateral Ventricles: A Case Report of an Unusual Ventriculoperitoneal Shunt Complication
}

\author{
Lateral Ventriküller Arasında Serbest Yüzen Şant Kateteri: Olağandışı \\ Ventriküloperitoneal Şant Komplikasyonu Olgu Sunumu
}

Fatih Serhat EROL, Hakan CAKIN, Sait OZTURK, Osman DONMEZ, Metin KAPLAN

Firat University, Faculty of Medicine, Department of Neurosurgery, Elazig, Turkey

Corresponding Author: Hakan CAKIN / E-mail: firatneurosurgery@gmail.com

\begin{abstract}
Ventriculoperitoneal (VP) shunt proximal tip disconnection is rarely seen as a shunt complication. Shunt dysfunction and hydrocephaly can develop due to this disconnection. Presented here is a case of a disconnection of the ventricular catheter from the shunt valve, which passed between both lateral ventricles by free floating in the brain CT. The patient was operated on for hydrocephaly. The dysfunctional shunt valve and peritoneal catheter were removed and a new VP shunt system was implemented. Although some publications report that the ventricular catheter can be disconnected from the shunt valve, can adhere to the intraventricular structures, and can be a source of infection, no studies similar to the current case were found in the literature reporting a free floating ventricular catheter between the lateral ventricles.
\end{abstract}

KEYWORDS: Hydrocephaly, Shunt dysfunction, Free ventricular catheter

öz

Ventriküloperitoneal (VP) şant proksimal ucunun ayrılması bir şant komplikasyonu olarak nadir görülür. Bu ayrılma sonucunda şant ayrılması ve hidrosefali gelişebilir. Burada ventriküler kateterin şant valfinden ayrıldığı ve her iki lateral ventrikül arasından geçip beyin BT filmlerinde serbest yüzer durumda görüldüğü bir olgu sunuyoruz. Hasta hidrosefali için ameliyat olmuştu. Disfonksiyonel şant valfı ve peritoneal kateter çıkarılıp yeni bir VP şant sistemi yerleştirildi. Bazı yayınlar ventriküler kateterin şant valfinden ayrılıp intraventriküler yapılara tutunabileceği ve bir enfeksiyon kaynağı olabileceğini belirtse de literatürde lateral ventriküller arasında serbest yüzen bir ventriküler kateter bildirecek şekilde mevcut olguyu benzer olan bir olgu saptanmadı.

ANAHTAR SÖZCÜKLER: Hidrosefali, Şant disfonksiyonu, Serbest ventriküler kateter

\section{INTRODUCTION}

VP shunt applications are the most commonly used methods in the treatment of hydrocephaly. The intraventricular migration of the parts of the VP shunt system is a rarely seen shunt surgery complication (5). This complication can cause shunt dysfunction and the development of the clinical findings of hydrocephaly.

This study discussed a 3-year-old female who was admitted with the clinical finding of shunt dysfunction. Her ventricular catheter was observed to be disconnected from the shunt valve in the brain $\mathrm{CT}$, in which the shunt catheter was floating in the opposite ventricle.

\section{CASE REPORT}

A 3-year-old female patient was admitted to emergency services due to complaints including vomiting, fever, and loss of appetite. Upon physical examination, she was apathetic and macro-cephalic, and skin turgor and tonus were decreased, and the 'setting sun sign' was positive. In the laboratory tests, anemia and an electrolyte imbalance were detected. The patient's medical history revealed that she had been operated on in another healthcare center due to meningomyelocele and non-communicant hydrocephaly, and VP shunt surgery was performed in the neonatal period. The brain $C T$ revealed that ventricular catheter of the VP shunt was not in its place and it was free within the left ventricle; furthermore the septum pellucidum was partially absent (Figure $1 \mathrm{~A}$ ). In the control brain tomographies, during medical treatment before the surgery, it was observed that the ventricular catheter, which passed between the two lateral ventricles due to a partially absent septum pellucidum, and rested in a vertical position within the right lateral ventricle (Figure 1B,C).

After the anemia and the electrolyte imbalance were treated, the patient was operated on in our clinic. During the operation, the non-functional shunt valve and peritoneal catheter were removed and a new ventriculoperitoneal shunt system was implanted. There is no clinical problem with a free floating 

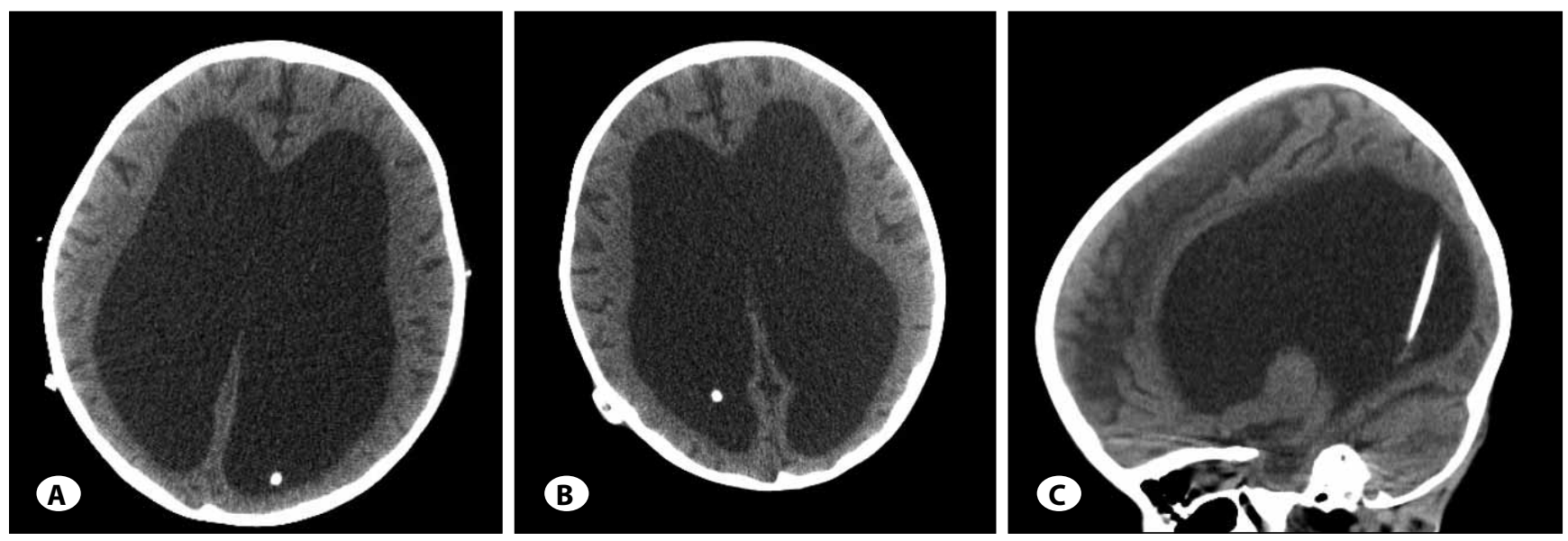

Figure 1: The free floating ventricular catheter and disconnected shunt valve between the right occipital bone. A) First Brain $\mathrm{CT}$ : Catheter in the left lateral ventricle and partially absent septum pellucidum. B) Preoperative Brain CT: Catheter in the right lateral ventricle. C) Preoperative Brain CT: Vertical position of the free ventricular catheter in the lateral ventricle.

ventricular catheter in the brain, and thus, it was not removed and follow-up was planned. After the surgery, the patient's neurological findings improved and she was discharged with medical treatment. In the controls performed one month later, it was observed that her neurologic examination was normal.

\section{DISCUSSION}

Shunt infection, migration, disconnection, obstruction, and shunt fracture are the primary complications of VP shunt surgery $(3,5)$. The migrations of the elements of VP shunt system toward the cranium are one of the complications that are rarely seen (5). The disconnection of the ventricular catheter from the shunt valve and its migration toward the cranium can be explained due surgical inattention and the negative intracranial pressure suction effect $(3,5)$.

Cerebrospinal fluid (CSF) is continuously produced at a 0.4-ml per-minute rate with an average rate of $20-\mathrm{ml}$ per-hour. CSF flows in a pulsatile manner, dependent on the cardiac rhythm. CSF, being associated with increasing intracranial blood flow and pressure in the cardiac systole, made from the cerebrum, passes through the lateral ventricles by means of Monro's foramen to the third ventricle, then to the fourth ventricle by the aqueduct cerebri, and to the pontine by passing through the cistern and flows within the spinal canal in the subarachnoid gap. In diastole, there is a return flow toward the lateral ventricles. The CSF flow speed and its direction can be measured non-invasively via Cine-Contrast MR. When CSF flow is obstructed at any level, hydrocephaly occurs $(6,7)$.

In the brain anatomy, lateral ventricles are separated from each other by the septum pellucidum. The septum pellucidum consists of two pieces referred to as the membranous septum and the septum verum. The complete or partial absence of the septum pellucidum in cranial pathologies such as Chiari type II, septo-optic dysplasia, schizencephaly, holoprosencephaly, encephalocele, aqueduct stenosis, corpus callosum agenesis, hydraencephalia can be seen. It has been reported that the partial absence of the septum pellucidum can be seen in patients with Chiari type II and aqueduct stenosis due to hydroencephaly. The current case reported that ventricular catheter was free-floating between the right and left lateral ventricles and that it was displacing. The researchers believe that the movement of the catheter occurs in association with the position of the head and with CSF flow dynamics as a result of the partial absence of the septum pellucidum. The free-floating ventricular catheter was vertical in the lateral ventricle occipital horn in all brain CTs. The researchers believe that the supine position during the $\mathrm{CT}$ and effect of gravity can be reasons for this.

Ventricular catheters can cause epileptic seizures as a result of adhesion and can also be the nidus for infection. In such cases, the ventricular catheter should be removed. Usually, catheter can be endoscopically removed. However, a craniotomy may be required in cases where the catheter is adhered to the parenchyma (4).

In case of surgical intervention for a free-floating ventricular catheter, the anatomic localization of the ventricular catheter should be determined on the operating table through the CT or C-Scopy (2). However, in the current study, since the free ventricular catheter did not cause any clinical evidence, it was not removed and follow-up was preferred.

\section{CONCLUSION}

Ventricular catheter dislocations may cause clinical manifestations, such as seizures and infections, in which cases the ventricular catheter should be removed. It is important to note that the localization of the catheter should be checked by $\mathrm{C}$ - Scopy or CT just before the surgery, the position of the patient and the surgery should be planned accordingly, and the probable surgical complications should be prevented. It should be kept in mind that septum pellucidum anomalies in long-term hydrocephaly patients, a free catheter can become 
displaced within the ventricle and can furthermore pass to the opposite ventricle through the defect that is present in the septum pellucidum.

\section{REFERENCES}

1. Benedetta LP, Frassanito P, Tamburrini G, Massimi L Caldarelli, Concezıo R: Retrieval of ventricular catheter with the aid of endoscopy. J Neurosurg Pediatrics 2: 71-74, 2008

2. Goeser CD, McLeary SM, Young WL: Diagnostic imaging of ventriculoperitoneal shunt malfunctions and complications. Radiographics, Scientific Exibit 18: 635-651, 1998

3. Hashiguchi K, Morioka T, Samura K, Miyagi Y, Yoshida F, Nagata S, Sasaki T: Medial temporal lobe epilepsy associated with misplacement of a ventricular shunting catheter. Journal of Clinical Neuroscience 15: 939-942, 2008

4. Pereira CU, Santos EAS: Intracranial migration of a ventriculoperitoneal shunt catheter. The Internet Journal of Pediatrics and Neonatology 4(2), 2005
5. Shaokoon C, Kristy T, Lynne EB:The effects of the interthalamic adhesion position on cerebrospinal fluid dynamics in the cerebral ventricles. Journal of Biomechanics 43:579-582, 2010

6. Weerakkody RA, Czosnyka M, Schuhmann MU, Schmidt E, Keong N, Santarius T, Pickard JD, Czosnyka Z: Clinical assessment of cerebrospinal fluid dynamics in hydrocephalus. Guide to interpretation based on observational study. Acta Neurolojica Scandinavia 124(2):85-98, 2011

7. Yi KC, Kim HS, Hong SR, Chi JG: Absence of the septum pellucidum associated with a midline fornical nodule and ventriculomegaly: A report of two cases. J Korean Med Sci 25: 970-973, 2010 